\title{
The Transcription Repressor REST in Adult Neurons: Physiology, Pathology, and Diseases ${ }^{1,2,3}$
}

\author{
(D)Pietro Baldelli,, ${ }^{1,3}$ and (1) Jacopo Meldolesi ${ }^{2,4}$
}

DOI:http://dx.doi.org/10.1523/ENEURO.0010-15.2015

${ }^{1}$ Department of Experimental Medicine, University of Genova, 16163 Genova, Italy, ${ }^{2}$ Department of Neuroscience, San Raffaele Scientific Institute, 20132 Milano, Italy, ${ }^{3}$ Department of Neuroscience and Brain Technologies, Istituto Italiano di Tecnologia, 16132 Genova, Italy, ${ }^{4}$ Vita Salute San Raffaele University, 20132 Milano, Italy

\begin{abstract}
REST [RE1-silencing transcription factor (also called neuron-restrictive silencer factor)] is known to repress thousands of possible target genes, many of which are neuron specific. To date, REST repression has been investigated mostly in stem cells and differentiating neurons. Current evidence demonstrates its importance in adult neurons as well. Low levels of REST, which are acquired during differentiation, govern the expression of specific neuronal phenotypes. REST-dependent genes encode important targets, including transcription factors, transmitter release proteins, voltage-dependent and receptor channels, and signaling proteins. Additional neuronal properties depend on miRNAs expressed reciprocally to REST and on specific splicing factors. In adult neurons, REST levels are not always low. Increases occur during aging in healthy humans. Moreover, extensive evidence demonstrates that prolonged stimulation with various agents induces REST increases, which are associated with the repression of neuron-specific genes with appropriate, intermediate REST binding affinity. Whether neuronal increases in REST are protective or detrimental remains a subject of debate. Examples of CA1 hippocampal neuron protection upon depolarization, and of neurodegeneration upon glutamate treatment and hypoxia have been reported. REST participation in psychiatric and neurological diseases has been shown, especially in Alzheimer's disease and Huntington's disease, as well as epilepsy. Distinct, complex roles of the repressor in these different diseases have emerged. In conclusion, REST is certainly very important in a large number of conditions. We suggest that the conflicting results reported for the role of REST in physiology, pathology, and disease depend on its complex, direct, and indirect actions on many gene targets and on the diverse approaches used during the investigations.
\end{abstract}

Key words: channels; excitotoxicity; mRNA splicing; neural genes; receptors; transcription repression

\section{Significance Statement}

Analysis of the role of REST (RE1-silencing transcription factor) in adult neurons, before and after stimulation and under pathological conditions, is presented for the first time, along with the available information about the role that the transcription repressor appears to play in diseases, especially in Alzheimer's disease and epilepsy. The development of these studies in the next few years is anticipated.

\section{General introduction}

REST [RE1-silencing transcription factor (otherwise called neuron-restrictive silencer factor)], a zinc-finger transcription factor initially described as a nuclear negative regu-

Received January 29, 2015; accepted June 18, 2015; First published July 01, 2015.

${ }^{1}$ The authors declare no competing financial interests.

${ }^{2}$ Author contributions: P.B. and J.M. analyzed data; P.B. and J.M. wrote the paper. lator of differentiation (Chong et al., 1995; Schoenherr and Anderson, 1995), is now known to play a master role in neuronal cells (Ballas and Mandel, 2005; Gopalakrishnan, 2009). The effects of REST on its potential target genes depend on various factors, including the accessibility of

\footnotetext{
${ }^{3}$ This research was supported by Grant GGP09066 from the Telethon Foundation.

Acknowledgments: For their collaboration in the studies of our laboratories, we thank our colleagues A. Contestabile, R. D'Alessandro, E. Ferrea, G.
} 
the specific DNA binding sequences, the binding affinity, and the cooperation and competition with other transcription factors (Wu and Xie, 2006; Johnson et al., 2012; McClelland et al., 2014). Upon DNA binding, REST operates as a scaffold, assembling and positioning its operative complexes that include, among others, important enzymes such as histone deacetylases and the demethylase LSD1. These complexes are able to repress the transcription of large numbers of genes by modifying critical sites of their histones and DNA (Huang et al., 1999; Ballas and Mandel 2005; Ooi and Wood, 2007).

For quite some time, the REST target genes were described as containing one to five RE-1s (otherwise called neuron-restrictive silencer elements), the DNA sequences binding REST, in their promoter and other regulatory regions. Over a thousand RE-1-positive genes were reported, many of which were encoding for neuron-specific proteins (Bruce et al., 2004; Mortazavi et al., 2006; Johnson et al., 2007). Later on, further studies, performed in both neuronal and non-neuronal cell types, defined the $\mathrm{RE}-1$ sequence as a subset of more numerous RESTbinding motifs (Johnson et al., 2007, 2012; Otto et al., 2007; ENCODE Project Consortium, 2012). As a consequence, the number of potential REST targets increased considerably (several thousands). The present list includes genes encoding for RNAs of various types, not only mRNAs, but also microRNAs (miRNAs), short hairpin RNAs (shRNAs), and long noncoding RNAs (ncRNAs; Johnson et al., 2009; Rossbach, 2011; Volvert et al., 2014).

To date, the majority of REST studies have been conducted on embryonic and neural stem cells, and on neural cells during differentiation (Sun et al., 2005; Greenway et al., 2007; Johnson et al., 2008). In embryonic stem cells, high levels of REST (Jørgensen et al., 2009), working coordinately with other factors such as the canonical pluripotency factors Oct4, Sox2, and Nanog, were shown to operate in the repression of a large number of genes (Johnson et al., 2008). In neural stem cells that still exhibit high REST levels, the numerous genes repressed by REST coincide only in part with those of embryonic stem cells (Johnson et al., 2008). In addition to repression, REST has been shown to promote gene expression, which has been reported at all stages of cell differentiation (Ooi and Wood, 2007; Jobe et al., 2012). Such a dual role of REST is due to its ability to cross talk with other factors, including those governed by the Polycomb complexes, which enables it to participate in regulatory networks of transcription.

Lignani, D. Pozzi, I. Prada, and G. Racchetti. In addition, we are grateful to a scientist friend, Anna Mondino, for her generous revision of the text.

Correspondence should be addressed to Jacopo Meldolesi, Department of Neuroscience, San Raffaele Scientific Institute, Vita Salute San Raffaele University, Via Olgettina 58, 20132 Milan, Italy. E-mail: meldolesi.jacopo@hsr.it. DOI:http://dx.doi.org/10.1523/ENEURO.0010-15.2015

Copyright (C) 2015 Baldelli and Meldolesi

This is an open-access article distributed under the terms of the Creative Commons Attribution 4.0 International, which permits unrestricted use, distribution and reproduction in any medium provided that the original work is properly attributed.
Neuronal differentiation soon reaches an advanced progenitor stage in which REST rapidly decreases to very low levels. This is due in part to the decreased control by two important regulators, $\beta$-catenin and HIPPI (HIP1 protein interactor; Willert et al., 2002; Nishihara et al., 2003; Datta and Bhattacharyya, 2011), that cooperate with the T-cell factor and SP1 transcription factors (Nishihara et al., 2003; Ravache et al., 2010). Moreover, over the course of differentiation SP1 is progressively replaced by its homolog SP3, with a further large decrease of transcription (Ravache et al., 2010). Concomitantly, a ubiquitinating enzyme, SCF-TRCP, which is specific for REST, undergoes rapid overexpression. An increase in the activity of this enzyme, which drives REST to proteolytic degradation, when accompanied by no change in the deubiquitinase enzyme HAUSP (Westbrook et al., 2008; Huang et al., 2011), greatly increases the turnover of REST.

The downregulation of REST is critical for the acquisition and preservation of neuronal specificities. The expression of REST-dependent genes activates a variety of important processes during advanced differentiation, such as axonal growth, the establishment of synaptic contacts, and membrane excitability (Paquette et al., 2000; Aoki et al., 2012). In the adult brain, all neurons exhibit low levels of REST (Fig. 1), although with some moderate heterogeneity (Palm et al., 1998; Calderone et al., 2003; Sun et al., 2005; Gao et al., 2011). Compared to the case in stem cells, the number of REST target genes is lower in adult neurons. The decrease of these genes, which is established during differentiation, is mostly a consequence of chromatin remodeling that reduces gene access to transcription (Murai et al., 2005; Abrajano et al., 2009; Yoo et al., 2009; Juliandi et al., 2010, Johnson et al., 2012).

Despite the low level of REST that is typical of adult neurons, the average level in whole-brain tissue is considerable. In fact, REST levels are high in most nonneuronal glial cells (Prada et al., 2011; Fig. 1), in endothelia and other cells of vessels, and in neural stem cells concentrated in specific areas (dentate gyrus of the hippocampus, subventricular zones, and a few others) where neurogenesis takes place (Gao et al., 2011). Outside the brain, low REST levels are typical of many neural cells. Other such cells, for example, many neuroblastoma cells, exhibit high REST levels; however, these levels decrease to neuronal levels upon long-term treatment with retinoic acid (Singh et al., 2011). In contrast, the levels of REST remain high in non-neural cells during and after differentiation. Downregulation in cells of this type occurs only in a fraction of tumors, where REST contributes to increased proliferation (Westbrook et al., 2005; Wagoner et al., 2010; Negrini et al., 2013a).

\section{Physiology}

The hypothesis that low levels of REST are necessary in neurons to enable the transcription of neural genes, which was put forth by Chong et al. (1995) in their discovery article, was supported and strengthened by many subsequent studies. By fine-tuning gene expression, REST also participates in chromatin plasticity (Ballas et al., 2005; 

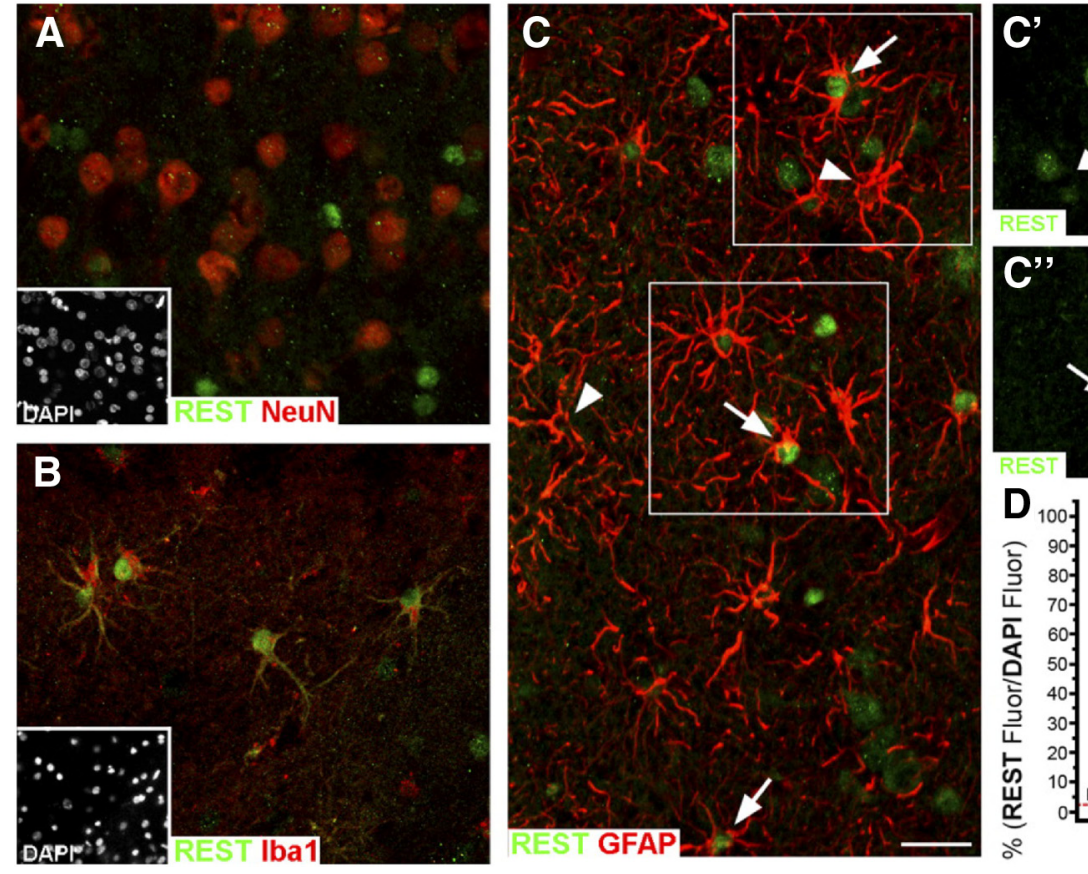
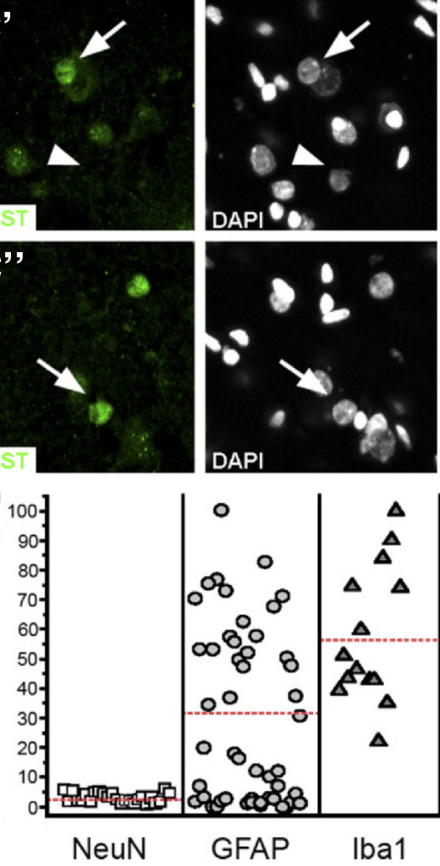

Figure 1 Expression of REST in various cell types in the human brain. Sequential slices were dually immunolabeled with an anti-REST antibody (green) together with antibodies against markers of various cell types (red). The REST immunolabeling is different in the various panels. $\boldsymbol{A}$, In neurons, no appreciable REST immunolabeling is present. $\boldsymbol{B}$, In microglia, nuclear REST immunolabeling is strong. $\boldsymbol{C}$, In astrocytes, nuclear REST immunolabeling is variable. C', C', Enlargements of the immunolabeling in the boxes in $\boldsymbol{C}$, confirming the variable REST immunolabeling in the nuclei of astrocytes. $\boldsymbol{D}$, Quantification of the nuclear REST data illustrated in $\boldsymbol{A}-\boldsymbol{C}$ is shown. Scale bar: (in $\mathbf{C}) \mathbf{A}-\mathbf{C}, 30 \mu \mathrm{m}$. The figure is from Prada et al., 2011.

Rodenas-Ruano et al., 2012). Many genes expressed in adult neurons are governed or related to REST. These include genes for transcription factors, dependent on REST for their repression, such as Sp1, Grin1, Asc/1, Is/1, and many others, as well as genes that are not repressed. The functions of these genes are influenced by REST, and this type of gene includes Creb, E47, Poh3f2, Gata2, Myod, and many others (Wu and Xie, 2006; Johnson et al., 2008; Moreno-González et al., 2008; Yuan et al., 2013; Bersten et al., 2014).

Among the other genes largely repressed by REST are those encoding for many channels and transporters, as well as presynaptic and postsynaptic proteins. These encoded proteins, in turn, ensure membrane excitability and synaptic transmission. The REST dependence of voltagegated $\mathrm{Na}^{+}$channels, which was already reported at the time that REST was discovered (Chong et al., 1995), has been confirmed several times (Nadeau and Lester, 2002; Drews et al., 2007; Pozzi et al., 2013). Additional channels, specifically $\mathrm{Ca}^{2+}$ and $\mathrm{K}^{+}$(Ariano et al., 2010; Ono and lijima, 2010; Uchida et al., 2010; van Loo et al., 2012) and the hyperpolarization-activated, cyclic nucleotide-gated channel HCN1 (McClelland et al., 2011a), are all REST dependent. Likewise, the upregulation of the chloride transporter $\mathrm{KCC}_{2}$ in adult cortical neurons relies on low REST levels. This transporter is critical for the $\mathrm{Cl}^{-}$switch that converts the function of GABA from excitatory to inhibitory (Uvarov et al., 2005; Yeo et al., 2009). In addition, REST governs the expression of critical subunits of nicotinic and glutamatergic (NMDA and AMPA) receptors
(Qiang et al., 2005; Moreno-González et al., 2008; Rodenas-Ruano et al., 2012), as well as of a few G-protein-coupled receptors (Kim et al., 2004; Formisano et al., 2007; Henriksson et al., 2014). Particularly interesting are the neurotrophins and their receptors. The repression of BDNF, which is induced by REST increases, has been envisaged as a potential risk for neuronal cells (Zuccato et al., 2007; Hara et al., 2009; however, see GarrigaCanut et al., 2006). Among the Trk receptors, the REST dependence of TrkC is also relevant for cancer development (Mulligan et al., 2008; Lawn et al., 2015). The common neurotrophin receptor, p $75^{\mathrm{NTR}}$, is also repressed by REST (Nakatani et al., 2005; Negrini et al., 2013b).

One of the neuron-specific processes controlled by REST is transmitter release. In this case, REST represses the genes that encode for synaptic vesicle proteins and those involved in vesicle exocytosis. These proteins include the specific SNAREs, neurotransmitter transporters, and other membrane proteins, and the proteins accumulated in the lumen (D'Alessandro et al., 2009) or exposed to the cytosolic surface of vesicles, such as the most abundant protein, synapsin 1 , which plays a crucial role in vesicle traffic and recycling (Schoch et al., 1996; Paonessa et al., 2013).

Other processes are important for REST physiology. Trafficking of the factor to the nucleus is needed for it to function. The process that has been specifically investigated (Shimojo, 2006) is the accumulation of the repressor in the nucleus, the compartment of its action. However, in various diseases such as Alzheimer's disease 
and Huntington's disease, the transport of REST to the nucleus is altered in various ways (for stimulation, see Zuccato et al., 2007; for depression, see Lu et al., 2014). A specific, important aspect of REST downregulation in adult neurons is its effects on miRNA expression, in particular $\mathrm{miR}-124, \mathrm{miR}-9 / 9 *$, and $\mathrm{miR}-132$, the expression of which is stimulated by another transcription factor, CREB (Wu and Xie, 2006), and is indeed reciprocal to REST. Therefore, the three miRNAs, which are abundant in resting neurons, decrease upon stimulation, causing REST levels to increase (Conaco et al., 2006; Wu and Xie, 2006; Sanuki et al., 2011; Sun et al., 2013). Each one of the miRNAs mentioned above has several functions, including, for miR-132, the regulation of neural tissue plasticity, synaptogenesis, and synaptic function (Siegel et al., 2011); and for miR-124 and miR-9/9*, the promotion of neuronal migration (Volvert et al., 2014) and the assembly of the ATP-dependent, chromatin remodeling BAF (Brahma-associated factor) complexes, which are essential for learning and memory (Yoo et al., 2009; Sun et al., 2013; Vogel-Ciernia et al., 2013). REST dependence is not restricted to miRNAs but extends to other types of neurally restricted, ncRNAs (Rossbach, 2011). A small dsRNA acts by competing with REST for target gene function (Kuwabara et al., 2005; Yoo et al., 2009). Moreover, a fraction of the long noncoding ncRNAs, which have neurally restricted expression, is also transcriptionally controlled by REST. Whether such REST control is relevant for neuronal cell physiology is unclear because the general function of ncRNAs also remains to be established (Johnson et al., 2009, 2014).

REST levels also control factors involved in alternative mRNA splicing, contributing significantly to neuronal specificity. For instance, REST controls the expression of nSR100, which operates on a large panel of mRNAs that are differentially spliced in neurons and non-neural cells (Raj et al., 2011). The mRNA for REST is among these. In neurons, REST frequently appears in its truncated, inactive form, REST4, which competes with full-length REST for the binding of target genes. Of note, the coexistence of the full length and the truncated forms attenuates the repression of REST target genes, and thus protects neuronal cells (Raj et al., 2011). Protection by REST4 was confirmed by studies of ethanol intoxication in control and REST knock-out mice (Cai et al., 2011). nSR100 also operates together with other neuron-specific, RESTdependent splicing factors. Its combination with Nova1 governs the splicing of the demethylase LSD1, a component of REST operative complexes. Short LSD1, the predominant form in neurons that results from mRNA splicing by the two factors, favors the disassembly of REST complexes. The final result of this dual splicing therefore mimics the effect of REST4 (Rusconi et al., 2014). Another REST-dependent factor, Nova2, induces the splicing of a key neural adhesion protein, L1CAM. While neurons express the full-length form of L1CAM, many non-neural cells express the shorter form, which exhibits poor homotypic binding and transmembrane signaling capacity (Mikulak et al., 2012). Because of its ability to control the expression of splicing factors, the number of REST- dependent gene products is much larger than the number of its direct gene targets. Accordingly, repression of the nSR100 and NOVO genes by increases in REST does ultimately alter the structure and function of whole synapses (Ule et al., 2005; Eom et al., 2013).

The level of REST in adult neurons is not always low. REST levels have been reported to increase progressively in the nuclei of hippocampal and brain cortical neurons in healthy, aging humans, possibly because of the increased frequency of stress and Wnt-controlled signaling. These findings correlate well with the upregulation of various protective genes and the downregulation of potentially toxic genes, resulting in the preservation of global cognition and increased neuronal longevity (Lu et al., 2014). Of note, nuclear REST levels do not increase in aging humans with brain diseases, especially in patients with Alzheimer's disease (see the discussion in the Alzheimer's disease section).

Neuronal excitation is also controlled by REST. Prolonged in vitro depolarization of neuronal primary cultures with high extracellular $\mathrm{K}^{+}$was reported to induce increases in REST accompanied by the downregulation of proteins encoded by target genes, including the neurotrophin BDNF (Hara et al, 2009) and the transcription factor NPAS4 (Bersten et al., 2014). Similar results were obtained when depolarization was induced in primary cultures of mouse hippocampal neurons by up to 4 days of treatment with 4-aminopyridine, a blocker of $\mathrm{K}^{+}$channels. The treatment, the effects of which were analyzed by patch-clamp and multielectrode array recordings, was shown to induce, in excitatory neurons, a transient increase in REST mRNA followed by an increase in the protein (Fig. 2A) and a progressive decline in action potential frequency (Pozzi et al., 2013). The effect was due to the decrease in both the firing frequency and density of $\mathrm{Na}^{+}$channels, which were identified as $\mathrm{Na}_{\mathrm{v}} 1.2$ channels (Fig. 2B). This decreased excitability corresponds to the decline of a well known neuronal condition, intrinsic homeostasis (Pozzi et al., 2013).

Studies of G-protein-coupled receptors have not included details about REST increases and gene target inhibition (Kim et al., 2004; Formisano et al., 2007; Henriksson et al., 2014). In contrast, studies with kainate, a glutamatergic agent that is active on channel receptors, that were first performed by Palm et al. (1998) and then by other groups (see, among others, Calderone et al., 2003; Spencer et al., 2006; Formisano et al., 2007; McClelland et al., 2011a, 2014; Orta-Salazar et al., 2014; RiveraCervantes et al., 2015), revealed the induction of REST upregulation in vivo in hippocampal and cortical neurons. Analogous results induced by prolonged treatment with the same agent were obtained in primary cultures of rat hippocampal CA1 neurons (Spencer et al., 2006; Lau and Tymianski, 2010; Ortuño-Sahagún et al., 2014; RiveraCervantes et al, 2015) and in brain slices prepared ex vivo (Calderone et al., 2003; McClelland et al., 2011a).

The majority of the studies reported to date have focused on specific processes of REST increases. They demonstrated the relevance of REST and provided information about the mechanisms involved. In these studies, 
A
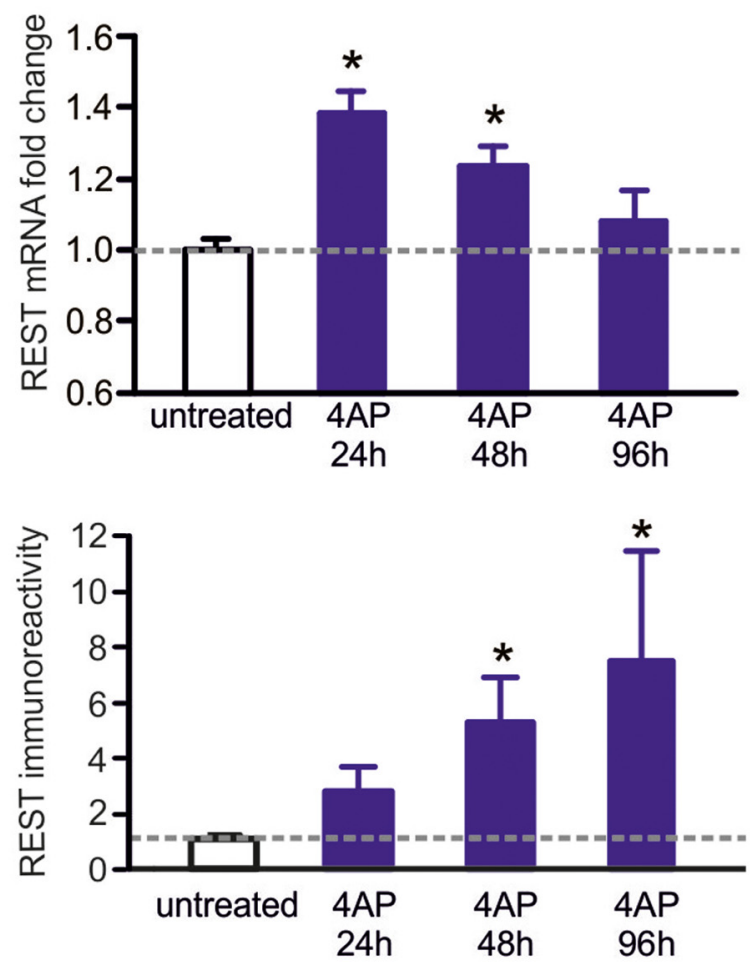

B
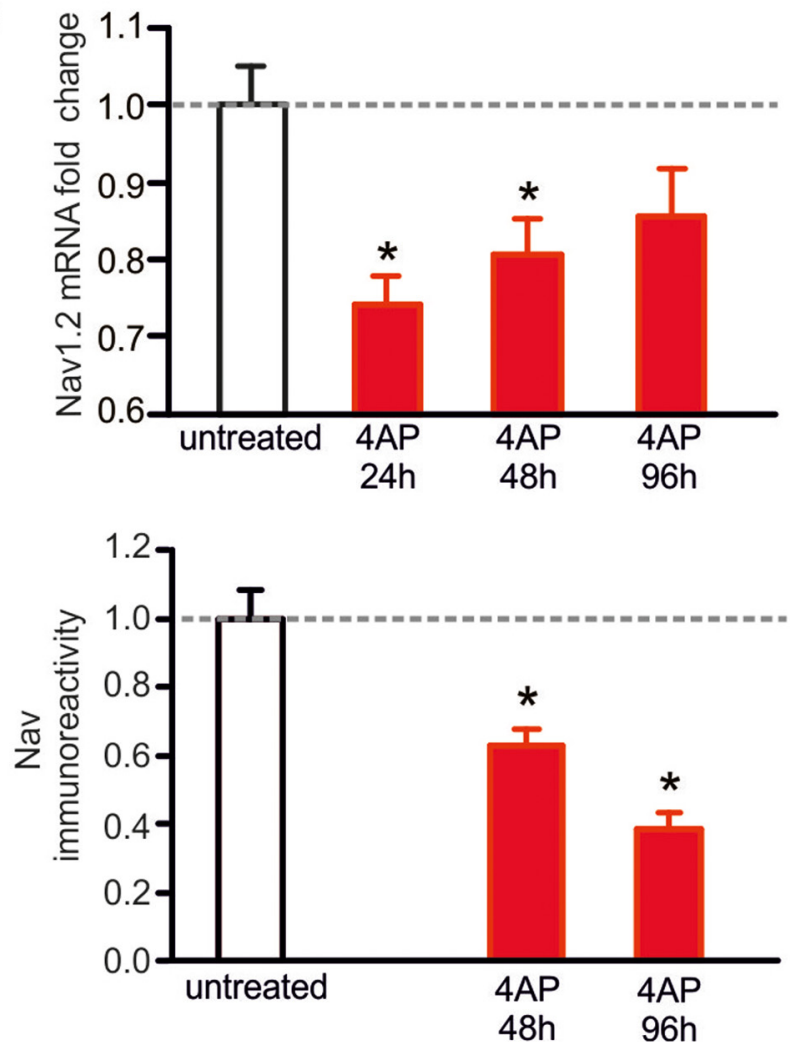

Figure 2 4-Aminopyridine (4AP)-induced cortical neuron hyperactivity increases REST expression and, in parallel, downregulates the expression of the $\mathrm{Na}^{+}$channel $\mathrm{Na}_{\mathrm{v}}$ 1.2. $\boldsymbol{A}$, Analysis of REST (blue). Top, Quantitative RT-PCR analysis of REST mRNA levels in cortical neurons that were either untreated or treated with 4AP $(100 \mu \mathrm{M})$ for 24,48 , and $96 \mathrm{~h}$. Bottom, Changes in the REST protein of cortical neurons treated as in the top panel,
Figure 2 continued

quantified by Western blotting. $\boldsymbol{B}$, Analysis of $\mathrm{Na}_{\mathrm{v}} 1.2$ (red). Top, Quantitative RT-PCR of the changes in $\mathrm{Na}_{\mathrm{v}} 1.2$ mRNA in cortical neurons, which were untreated or treated with 4AP as in $\boldsymbol{A}$. Bottom, $\mathrm{Na}_{\mathrm{v}} 1.2$ protein of cortical neurons treated as in $\boldsymbol{A}$, quantified by Western blotting. Notice that, for both mRNA and protein, the opposite changes were induced by 4AP: an increase in REST mRNA at $24 \mathrm{~h}$, followed by a decrease back to the untreated level at $96 \mathrm{~h}$, accompanied by a decrease of $\mathrm{Na}_{\mathrm{v}} 1.2$ mRNA, and followed by an increase at the same times; and a slow increase in REST protein (up to approximately eightfold at $96 \mathrm{~h}$ ) accompanied by a slow decrease in $\mathrm{Na}_{\mathrm{v}} 1.2(\sim 40 \%$ at $96 \mathrm{~h})$. The data in the columns in $\boldsymbol{A}$ and $\boldsymbol{B}$ (mean \pm SEM) were obtained from seven to eight (top) and four (bottom) samples from two separate neuronal preparations. $* p<0.05$, Kruskal-Wallis test followed by Dunn's test versus untreated. The figure is from Pozzi et al., 2013.

however, comprehensive analysis of the changes in gene expression induced by the increased levels of REST was not performed. Detailed information about this issue was first provided by a recent study performed by McClelland et al. (2014), in which mice were exposed to kainate. In this study, the expression of $>400$ classic REST gene targets, including the RE-1 sequence in their regulatory domains, was investigated after increases in REST levels of a few fold. The expression of only a relatively small $(\sim 10 \%)$ fraction of these genes, characterized by intermediate affinity for the repressor, was found to significantly decrease (McClelland et al., 2014). Analysis of the genes of this fraction revealed that they encode voltagegated and receptor channels (including, among others, $\mathrm{Na}^{+}$and $\mathrm{K}^{+}$channels, glutamatergic receptor subunits, the $\mathrm{HCN} 1$ voltage-gated channel, and the $\mathrm{Cl}^{-}$transporter $\mathrm{KCC} 2$ ), together with signaling proteins, some kinases, transcription factors, and a few other proteins (McClelland et al., 2014). The genes with high and low binding affinity, which were already demonstrated to exhibit considerable and minor repression, respectively, before stimulation, were found to undergo no appreciable change after kainate stimulation (Fig. 3). The REST dependence of the results obtained with the various target genes was demonstrated by experiments in which the tone of the repressor was attenuated by the introduction of decoy oligodeoxynucleotides comprised of the RE-1 binding sequence (McClelland et al., 2014). Currently, not all of the genes that modify their expression following stimulationinduced changes in REST may have been identified. Yet, the results of the McClelland et al. (2014) study are expected to have important implications for the interpretation of the REST target gene expression results. It is clear, in fact, that the genes affected by stimulation-induced increases in REST are numerous and that many of them are functionally relevant. At least some of the proteins encoded by these genes could operate not separately but coordinately with each other.

A final problem to be considered addresses the possible role of REST in excitotoxicity, a process of neuronal death that is known to be induced by glutamate and its analogs (Spencer et al., 2006; Lau and Tymianski, 2010; 


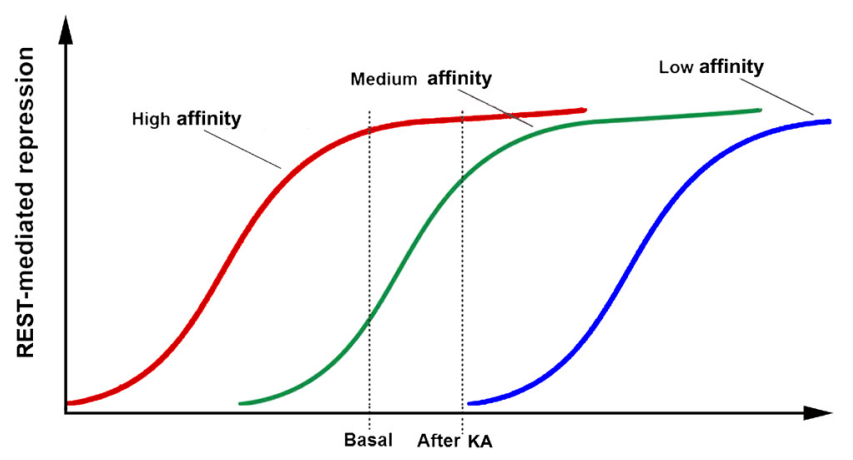

Figure 3 REST binding affinity dependence of neuronal gene repression. The figure illustrates the average changes in the repression induced by increases in REST levels in three groups of RE-1-positive genes, which were dependent on their average binding affinity. The genes with high affinity (red) are already $100 \%$ repressed at basal levels of REST. The genes with intermediate affinity (green), which are $\sim 30 \%$ repressed at basal levels, exhibit an increase in their repression to $\sim 80 \%$ upon cell treatment with kainate $(\mathrm{KA} ; 6 \mu \mathrm{M})$. The low-affinity genes are repressed neither at basal levels nor after KA and would require higher levels of REST to be repressed. The figure is from McClelland et al., 2014.

Pozzi et al., 2013; Ortuño-Sahagún et al., 2014; RiveraCervantes et al., 2015). Two findings may be important when discussing the possible contribution of REST to this process. First, the excitotoxicity elicited by glutamatergic agents reported in the studies described above was not reported in others (Palm et al., 1998; McClelland et al., 2011a). This variability has been proposed to depend on a protective intracellular MAPK-ERK signaling cascade that is triggered by the same glutamatergic agents (OrtuñoSahagún et al., 2014). Second, depolarizing agents such as high $\mathrm{K}^{+}$and 4-aminopyridine, which induce increases of REST analogous to those of glutamatergic agents, do not induce any excitotoxicity (Hara et al, 2009; Pozzi et al. 2013; Bersten et al., 2014). Based on these considerations, the role of REST appears to consist not in the induction but at most in the strengthening of the excitotoxic effects induced by the glutamatergic agents.

\section{Pathology}

In the last paragraph of the previous section, we concluded that REST may not play a dominant role in the excitotoxicity triggered in neurons by glutamatergic agents. Nevertheless, the possibility of a contribution of REST to the toxicity induced by glutamate (Spencer et al., 2006; Pozzi et al., 2013) or polychlorinated biphenyls (Formisano et al., 2014) appears quite likely. A similar conclusion may also be valid for a neural cell line exposed to oxygen-glucose deprivation. In the cells of this line, an increase in REST was shown to act via antagonism of the well known transcription factor CREB (Wu and Xie, 2006), with ensuing downregulation of CART (cocaine and amphetamine-regulated transcript), a secretory peptide known to exert neuroprotective effects (Zhang et al., 2012).

The most detailed studies emphasizing the role of REST in brain pathology were performed in rats exposed to global brain ischemia due to in vivo electrocauterization of vertebrate arteries followed by occlusion of the carotid arteries (Calderone et al., 2003). These treatments generate a condition similar to that of stroke. In light of this similarity, the data from these studies will be attributed to this type of pathology. In the first stage, successive increases in REST mRNA and protein were found to occur in CA1 pyramidal neurons of organotypic hippocampal slice cultures 24-48 $\mathrm{h}$ after stroke. The increase in REST was shown to downregulate the expression of various targets, including the gene encoding for the GluR2 subunit of the glutamatergic AMPA receptor (Calderone et al., 2003; Jia et al., 2006). Death of the insulted CA1 neurons was found to take place $7 \mathrm{~d}$ after stroke. Neither the increase in REST nor the subsequent death observed in CA1 occurred in other hippocampal neurons, such as CA3 pyramidal neurons and the granule neurons of the dentate gyrus (Calderone et al., 2003).

Further studies performed by the same research group investigated the mechanisms of the CA1 neuronal death associated with the increase in REST induced by stroke. In addition to the AMPA subunit, stroke was shown to affect the NMDA receptor by inducing the replacement of the GluN2B subunit with the GluN2A subunit. These changes were accompanied by a selective increase in synaptic transmission (Rodenas-Ruano et al., 2012). The REST increase was found to occur only in animals that did not express casein kinase 1, an enzyme that participates in the regulation of the ubiquitin-based degradation of REST (Kaneko et al., 2014). The number of genes downregulated by the increase of REST in these neurons was relevant (Noh et al., 2012) and included the $\mu$ opioid receptor gene (Formisano et al., 2007). Among these genes was one encoding for miR-132, which appeared to be causally related to neuronal death (Hwang et al., 2014). Unexpectedly, the repression of miR-132 was not accompanied by changes in miR-124 and miR-9/9* (Hwang et al., 2014), two neuronal miRNAs that are also expected to operate reciprocally to REST (Conaco et al., 2006). Together, the data presented in this section suggest that the increases in REST induced by stroke or toxic treatments contribute to neuronal death by affecting the expression of numerous genes and their encoded proteins; whereas, other, non-death-inducing genes may be changed less or not at all.

\section{Diseases}

\section{Brain diseases}

In light of the key role of REST in brain development and function, it is not surprising that it also plays mechanistic roles in the pathogenesis of several brain diseases. REST is also known to be involved in the biogenesis of brain tumors; however, this will not be discussed here as it was recently reviewed elsewhere (Huang and Bao, 2012; Negrini et al., 2013a). Rather, the following sections will summarize the present knowledge of the role of REST in several brain diseases as well as in terms of therapy. 


\section{Psychiatric diseases \\ Schizophrenia}

The pathogenesis of schizophrenia, the most important psychiatric disease, is widely believed to include the deregulation of a number of genes, the so-called schizophrenia-associated genes, which have been identified by genome-wide approaches. One of these associated genes encodes for SMARCA2, a member of the switch/sucrose nonfermentable (SWI/SNF) chromatinremodeling complex that is known to operate under the control of REST. Studies in neural cell lines and a transgenic mouse model showed that the interaction between SWI/SNF and REST can attract $80 \%$ of the other associated genes, suggesting the possible role of a large, RESTcontaining complex in the so-called genetic architecture of schizophrenia (Loe-Mie et al., 2010).

\section{Other mental diseases}

Several diseases of this group are based on classic genetic mechanisms. X-linked mental retardation was reported to depend on SMCX demethylase 5C, an enzyme that demethylates the K4 site of histone $\mathrm{H} 3$, which is critical for the activity of the REST complexes. Loss of the SMCX enzyme was found to impair REST-mediated downregulation of many neuronal genes, thus contributing significantly to the mechanism of the disease (Tahiliani et al., 2007). Another frequent form of mental retardation is part of Down syndrome, which results from trisomy of chromosome 21. The alteration of REST function reported in this disease was found to depend on overexpression of the protein DYRK1A, which is encoded by a gene of the trisomic chromosome. Work in various transgenic mouse models showed that DYRK1A binds SWI/SNF, the chromatin-remodeling complex regulated by REST, and is also involved in the pathogenesis of schizophrenia. In adult mouse neurons, the DYRK1A binding protein was shown to cause an increase in REST, with ensuing alterations in gene expression, and a severe reduction in dendritic growth and complexity. When the Dyrk1a gene was downregulated, these alterations were prevented. The conclusion is that REST, via its regulation of the SWI/SNF chromatin complex, contributes significantly to the neural phenotypic changes that characterize the disease (Canzonetta et al., 2008; Lepagnol-Bestel et al., 2009).

Dynorphin is an endogenous, proteolytically processed opioid protein known to give rise to many secretory peptides ( $\beta$-neoendorphin, dynorphin, leu-enkephalin, and a few others) that are all ligands of the $\kappa$-type opioid receptor. Expression of these peptides has been found to be altered in the brains of many patients with mental disorders, including drug addiction and some forms of schizophrenia (Tejeda et al., 2012). REST is known to repress the expression of most secretory proteins (D'Alessandro et al., 2009). The hypothesis of this disease is that mental disorders are elicited by the decreased expression of opioid proteins and peptides induced by the upregulation of REST, possibly as a consequence of the decreased expression of the reciprocal miRNAs miR-132, miR-9/9*, and/or miR-124 (Henriksson et al., 2014).

\section{Neurological diseases}

Alzheimer's disease

For many years, intensive studies of the mechanisms of the pathogenesis of Alzheimer's disease, which affects a considerable fraction of elderly humans, did not consider the possible involvement of REST. Interestingly, however, various factors now recognized as being REST dependent, such as miRNAs (including miR-9/9* and miR-132, which operate reciprocally to REST) and ncRNAs, have been proposed to play significant roles in Alzheimer's disease (Schonrock et al., 2012; Lau et al., 2013; Wu et al., 2013).

Two interesting studies recently rejuvenated interest in the role of REST in Alzheimer's disease. In the first study, investigation of brains from patients and a specific transgenic mouse model revealed considerable increases in REST with concomitant decreases of choline acetyltransferase (the key enzyme of acetylcholine biosynthesis) in neurons in the area of the nucleus of Meynert and in fibers traveling to the frontal and motor cortices, and to hippocampal area CA1. In light of the REST dependence of choline acetyltransferase expression and the relevance of cholinergic neurons in the development of the disease, the increase in REST was hypothesized as a mechanism of the induction of the overexpression and accumulation of $\beta$-amyloid and other proteins involved in neuronal degeneration (González-Castañeda et al., 2013; OrtaSalazar et al., 2014).

The other study, performed in humans and mouse models, demonstrated that in Alzheimer's disease and other neurodegenerative diseases, such as frontotemporal dementia and dementia with Lewy bodies, the level of REST in neurons of the hippocampus and frontotemporal cortices does not increase in the nuclei, as observed in healthy aging humans, but remains in the cytoplasm, where it accumulates within autophagosomes together with misfolded proteins (Lu et al, 2014). In other areas of the brain, such as the dentate gyrus and the cerebellum, that are not affected by Alzheimer's disease, the concentration of REST in nuclei was as high as in control subjects. Together, the results obtained by Lu et al. (2014) in the brains of healthy humans and Alzheimer's disease patients suggest that REST plays a critical role in neuronal viability. The development of neurodegenerative diseases may thus be favored by the expression of genes and processes related to neuronal degeneration, which, in the brains of healthy, aging humans, may be repressed by REST (Lu et al., 2014).

\section{Parkinson's disease}

Compared to the studies on Alzheimer's disease, those related to the role of REST in the Parkinson's disease appear less conclusive. REST was first investigated by treating a human dopaminergic neural cell line, SH-SY5Y, with $\mathrm{MPP}^{+}$, a neurotoxin known to affect dopaminergic neurons. In these studies, REST was found to elicit deleterious effects on SH-SY5Y cell viability (Yu et al., 2009). Subsequent analysis in a spontaneous autosomalrecessive rat model revealed the deregulation of several miRNAs, in particular of miR-132, followed by the degradation of dopaminergic neurons in the midbrain. In light of 
its reciprocal operation with miR-132, levels of REST were probably increased, as apparently confirmed by the accompanying decrease of BDNF, a neurotrophin encoded by a REST target gene. These results were interpreted as a suggestion of the involvement of a decrease in miR-132, and possibly an increase in REST, in the degradation of Parkinson's disease-specific neurons (Siegel et al., 2011; Lungu et al., 2013).

On the other hand, in recent experiments performed in REST knock-out mice, the administration of MPTP, a toxin known to elicit the appearance, in both humans and animals, of parkinsonian disorders due to the degeneration of dopaminergic neurons in the striatum, induced dramatic losses of those neurons. These results were interpreted as depending on the high vulnerability of the striatal neurons in knock-out mice (Yu et al., 2013). However, as discussed in detail in the Epilepsy section, the results induced in the neurons of REST knock-out animals are complex, involving the cooperation of numerous target genes. Therefore, the interpretation of the data by $\mathrm{Yu}$ et al. (2013) remains unclear.

\section{Huntington's disease}

In this disease, the neurodegeneration, which affects the basal ganglia and cerebral cortex in particular, is widely attributed to the mutant form of a specific protein, huntingtin. The mutant form is characterized by the extension of the N-terminal polyglutamine repeat. After investigations in animal models and in human brains postmortem, the disease was initially proposed to be a consequence of the accumulation of REST in the nuclei of neurons, which was favored by the huntingtin mutant and resulted in the repression of important target genes, such as the one encoding the neurotrophin BDNF (Zuccato et al., 2003). The attenuation of REST expression in neurons was found to restore BDNF levels, confirming the REST dependence of the aberrant gene transcription in this disease (Zuccato et al., 2007). In addition, mutant huntingtin has been found to induce effects other than the decreased expression of BDNF. In particular, Sp1, a transcription factor that has a role in the control of Rest gene expression, was found to be upregulated (Ravache et al., 2010). Concomitant investigation of thousands of direct target genes of REST identified dysregulation, not only in mRNAs and proteins but also in other RNAs, including both miRNAs and long ncRNAs (Bithell et al., 2009; Buckley et al., 2010). Abnormal changes, not only transcriptional but also epigenetic, have also been emphasized in the brains of Huntington's disease patients (Bithell et al., 2009; Buckley et al., 2010). Finally, recent results have revealed a variety of additional defects, including increased autophagy (Martin et al., 2015), altered mTORC (mammalian target of rapamycin complex 1) metabolism (Lee et al., 2015), and enhanced microglial reactivity (Crotti et al., 2014) in the neurons of Huntington's disease patients. Whether REST has a role in these altered processes remains to be investigated.

\section{Epilepsy}

Epilepsy, the third most common disease of the human brain, is the one in which the role of REST has been investigated in the most detail. Epilepsy is known to de- velop when the brain is injured or when the tendency to generate seizures evolves into an enduring process that is inextricably distributed among neuronal circuits, converging at the level of dysfunction. This conversion appears to be sustained by epigenetic alteration of important genes (Jessberger et al., 2007; McClelland et al., 2011a,b; Roopra et al., 2012; Goldberg and Coulter, 2013). REST and changes in the expression of its target genes have been envisaged as critical events governing later development of the disease. However, the mechanisms involved are still being debated.

In the literature of epilepsy, a few reports have emphasized the role of REST in the induction of the disease and possibly also in protection from it. Ten years ago, a 2-deoxy-D-glucose ketogenic diet was reported to have an antiepileptic effect via the activation of a chromatin remodeling complex controlled by an increase in REST (Garriga-Canut et al., 2006). Recently, however, the ketogenic diet has been shown to maintain its antiepileptic effect even in the absence of the REST increase (Hu et al., 2011b)

Additional studies found that the susceptibility to kindling and enhanced mossy fiber sprouting was greatly worsened in mice bearing a conditional deletion of REST in forebrain neurons. Based on these results, the REST increases induced by seizures were suggested to operate favorably in the patients, slowing down the development of epileptogenesis in the limbic cortex (Hu et al., 2011a). Further experiments in conditional knock-out mice were performed on neurons of the forebrain. Using the pentylenetetrazole model of acute seizures, the authors observed that in the knock-out mice, higher doses of the drug were needed to induce tonic convulsions and death (Liu et al., 2012). Although these studies were technically convincing, their interpretation remained open to question. In fact, the deletion of REST in neurons that have not started epileptogenesis is expected to induce the expression of large numbers of target genes, including those bound by REST with high affinity (Fig. 3), which in control neurons remain at least partially repressed even at rest (McClelland et al., 2014). Therefore, the increased epileptic responses observed in REST conditional knock-out mice could be due to genes not involved in the regular epileptogenic process.

On the other hand, McClelland et al. (2011a) reported exciting results regarding the role of HCN1, a hyperpolarization-activated, cyclic nucleotide-gated channel. HCN1 is known to play major roles in the control of neuronal excitability, synaptic transmission, and oscillatory activity, in both single neurons and neuronal networks. In the mouse model of temporal lobe epilepsy induced by kainate, the expression of HCN1 and the activation of specific currents were repressed by an increase in REST (McClelland et al., 2011a). Subsequent studies revealed that the repression resulting from an increase in REST was not limited to HCN1 but also included $10 \%$ of the analyzed target genes, including those encoding other channels and signaling proteins (see details in the Physiology section). The attenuation of REST binding to the RE- 1 sequence of the DNA of its target 


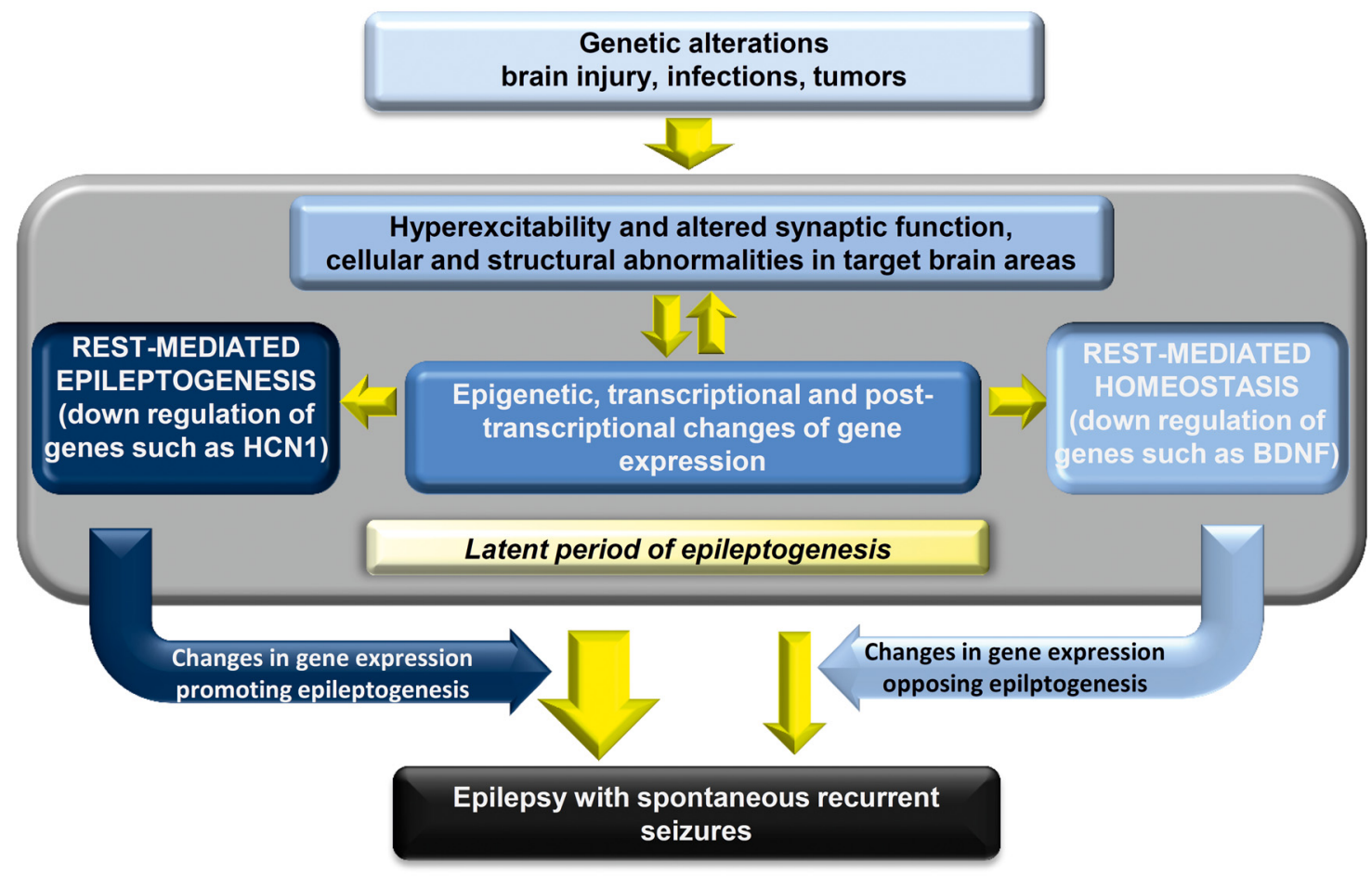

Figure 4 Epileptogenesis: sequence of events, including the role of REST. Causal processes that are possibly involved in the beginning of epileptogenesis are listed in the azure box at the top. Several boxes included in the middle profile (gray) summarize the subsequent events. Hyperexcitability and other structural and functional alterations (top, azure box) are directly connected to the causal processes at the top and to the changes in gene structure/expression of the central box. The appearance of epilepsy, however, is not rapid. Time is needed to convert the first seizures to an enduring process distributed to neuronal circuits. This maturation is not described; instead, it is just mentioned in the thin yellow box at the bottom of the green profile. The gene expression events governed by REST are shown in the two boxes connected to the central box. The blue box to the left includes the predominant genes whose repression promotes epileptogenesis; the clear azure box to the right includes the genes that tend to maintain cell homeostasis and thus to negatively modulate epileptogenesis. The difference in the relevance of the two modulations of REST-dependent genes is illustrated by the different thicknesses of the yellow arrows that receive their modulation. The resulting ongoing epilepsy is indicated in the black box at the bottom.

genes via specific decoy oligonucleotides was found to elicit not only a restoration of specific currents but also a reduction of the initial pattern of seizures (McClelland et al., 2014).

In conclusion, the results of studies of the role of REST in epilepsy might appear contradictory. It should be emphasized, however, that conditional deletion of REST before epileptogenesis induces the overexpression of many genes (Hu et al., 2011a; Liu et al., 2012), which may differ in various cell types. In contrast, the protective role of the attenuation of REST activity, as shown by McClelland et al. (2014) after the induction of status epilepticus, clearly documents the participation of increased REST levels in the establishment of the enduring process. This role of REST most likely includes epigenetic effects on many genes with intermediate affinity for the repressor. The overall range of events occurring during epileptogenesis, including the possibly variable role of REST in this process, is illustrated in Figure 4.

\section{Therapy with drugs related to REST}

In light of the relevance of REST in the physiology and pathology of adult neurons, it is not surprising that investments have been made toward the development of specific drugs that could function in a few of the diseases presented so far. At the moment, however, only two approaches have been developed toward translation. The first involves the use of analogs of valproic acid, a drug identified a few decades ago that is used in therapy for various forms of epilepsy. The actions of valproic acid were initially attributed to an enhancement of central GABAergic neurotransmission, possibly combined with the inhibition of $\mathrm{Na}^{+}$channels (Tunnicliff, 1999). It should be noted, however, that valproic acid, which is a highaffinity inhibitor of histone deacetylases, is not specific for the forms 1 and 2 of the enzyme, which are critical for the transcriptional repression by REST. It also acts on the other 16 forms of the enzyme, which are involved in many additional functions (Göttlicher et al., 2001). Studies were therefore started, and are still being performed, to identify new drugs that work with mechanisms analogous to those of valproic acid but that are specific to deacetylases of the first class. Because of their specificity, these drugs, and possibly also their inhibitors, might be used in therapies for numerous brain defects and diseases, including neurodegenerative disorders as well as defects of learning and memory, and of cognition (Gräff and Tsai, 2013; Penney and Tsai, 2014; Didonna and Opal, 2015). 
A second approach was developed for the treatment of Huntington's disease. As specified in a preceding section, one of the mechanisms contributing to Huntington's pathogenesis is the increased accumulation of REST in neuronal nuclei, possibly due to a peculiar function of the mutant huntingtin protein that reinforces the transport of the repressor across the nuclear envelope (Zuccato et al., 2003, 2007). The results of experiments in Huntington's disease cell cultures transfected with a dominantnegative REST construct had already documented the importance of the elevated nuclear REST levels and the resulting increased repression of target genes in the diagnosis of the disease (Zuccato et al., 2007). Further evidence along this line has been generated more recently by the use of decoys, double-stranded oligodeoxynucleotides that compete with REST for binding to the RE-1 sequence of DNA (Soldati et al., 2011). Decoys were also found to attenuate the repression of gene expression induced in neurons by kainate treatment (McClelland et al., 2014). In the meantime, two pharmacological approaches have been developed based on the selection, by high-throughput screening, of drugs that were later analyzed in various cell lines and in vivo in animals. The first drug was found to reduce nuclear accumulation of mSin3b, a corepressor of the REST N-terminal operative complex (Conforti et al., 2013), and the second drug was found to decrease cell levels of REST by stimulating its degradation (Charbord et al., 2013). Upon application of either one of these drugs, various REST target genes were shown to increase their levels. In the future, other drugs that interfere with the role of REST in neurons are expected to be developed. The interest in such developments could involve not only Huntington's disease but also other brain diseases in which changes in REST are critical for pathogenesis.

\section{Concluding remarks}

During the last 15 years, growing interest in the role of REST in adult neurons has paved the way to the identification of multiple, highly interesting processes that take place in the physiology and pathology of the brain as well as in several brain diseases. Although the number of REST-repressed genes is lower in adult neurons than in neural stem cells and early precursors (Sun et al., 2005; Greenway et al., 2007; Johnson et al., 2008), the functional relevance of most of them is considerable. Therefore, the identification of REST as a master factor, which was initially proposed for differentiating precursors (Ballas and Mandel, 2005), appears to be appropriate for adult neurons as well.

Among transcription factors, REST exhibits several unique properties. The very low levels of REST, which are initially established during differentiation, are maintained in adult neurons by controlled transcription of the Rest gene, coupled to the very active ubiquitination and ensuing proteolysis of the REST protein. The unusual length and repetitive structure of $R E-1$, the DNA sequence of REST binding in many target genes, ensures that the repressor has highly specific actions. Additional binding sequences are now under investigation; therefore, a re- port regarding their properties would be premature. The unique properties of REST and its actions, which are important in adult neurons, appear destined to undergo further development in the near future. Among the examples of important properties being investigated now and in the near future, a few are presented here.

High expression of many REST-dependent genes in neurons was shown to be reinforced by splicing mechanisms, such as generation of the inactive, truncated form of REST, REST4 (Raj et al., 2011). Strengthening of low REST action by REST4 has been confirmed by the study of ethanol intoxication (Cai et al., 2011). In the future, this reinforcement could be further increased. In fact, additional REST-dependent splicing factors are expected to be identified. The same is true for ncRNAs. At the moment, we are aware of three miRNAs that operate reciprocally to REST (Conaco et al., 2006). Whether other miRNAs and ncRNAs participate in the regulation of repressor function in neurons is still unknown (Johnson et al., 2009, 2014).

With respect to gene transcription, REST is highly efficient. Therefore, the repression of single target genes is usually thought to be its only function. Among other transcription factors, however, cooperation in the expression of single genes is quite common. In the case of REST, a cooperation that is widely accepted is with the Polycomb complexes (Arnold et al., 2013; Dietrich et al., 2012); however, additional instances of cooperation appear to exist (Wu and Xie, 2006; Johnson et al., 2008) and might be identified soon. REST-mediated repression of target genes encoding transcription factors is also highly interesting. When the transcription factors involved are other repressors, REST is expected to counteract the repression of their targets; if the transcription factors are stimulatory, REST is expected to indirectly extend the repression of their target genes. Currently, only a few transcription factors known to play a role in the indirect actions of REST have been identified (Ooi and Wood, 2007; Jobe et al., 2012). New factors are therefore expected to be identified soon.

Highly interesting has been the identification of intermediate affinity REST targets, such as the genes that are downregulated upon small increases in the repressor (McClelland et al., 2014). These genes, which comprise $\sim 10 \%$ of the investigated targets expressing RE- 1 sequences in their promoter or other regulatory areas, may be only a fraction of the number of genes that are downregulated by an increase in REST. In fact, other REST target genes are known to express binding sequences different from RE-1 (ENCODE Project Consortium, 2012). Moreover, additional REST target genes could be repressed/stimulated by indirect mechanisms (Ooi and Wood, 2007; Jobe et al., 2012). The identification of the majority of the target genes repressed upon cell stimulation might ultimately also be useful in accounting for the differential effects of REST, such as its apparently variable role in cell death/survival, which has been observed in different experimental conditions.

The most exciting developments in the REST area are expected in the field of diseases. In the case of at least 
some psychiatric diseases, the most interesting finding will be a conclusive explanation of the mechanisms of REST action. At the moment, these mechanisms are conceived of only in general terms. In the case of neurologic diseases, additional studies, both in vivo and in various experimental conditions, are expected to carry out critical analysis of the various effects of moderate REST increases. Currently, the REST increases that occur in Alzheimer's disease have been reported to be neuroprotective (Lu et al., 2014), while those in Huntington's disease and epilepsy have been reported to contribute to the pathogenetic process ( Zuccato et al., 2007; Bithell et al., 2009; Buckley et al., 2010; McClelland et al., 2011a, 2014). The other developments we expect in the field involve therapies. Currently, the studies of valproic acid do not appear promising. In contrast, this might be the case for the drugs developed for therapies for Huntington's disease. This and other approaches suggest that new pharmacological initiatives should be requested to rejuvenate the therapy for other brain diseases.

In conclusion, investigation of the roles and mechanisms of action of REST in adult neurons is still open, with at least potentially exciting avenues. Developments are expected to take place in both basic and translational fields. Possible pharmacological developments might ultimately have a considerable medical and social impact, which could be important, especially in aging populations. Further reviews in this area that are focused on at least some of the developments specified here, and include investigations using new experimental and technological approaches, could be needed in the next few years.

\section{References}

Abrajano JJ, Qureshi IA, Gokhan S, Zheng D, Bergman A, Mehler MF (2009) REST and CoREST modulate neuronal subtype specification, maturation and maintenance. PLoS One 4:e7936. doi: CrossRef. [PMC] [10.1371/journal.pone.0007936] [Medline]

Aoki H, Hara A, Era T, Kunisada T, Yamada Y (2012) Genetic ablation of REST leads to in vitro-specific derepression of neuronal genes during neurogenesis. Development 136:667-677. CrossRef

Ariano P, Zamburlin P, D'Alessandro R, Meldolesi J, Lovisolo D (2010) Differential repression by the transcription factor REST/ NRSF of the various $\mathrm{Ca}^{2+}$ signalling mechanisms in pheochromocytoma PC12 cells. Cell Calcium 47:360-368. CrossRef Medline

Arnold P, Schöler A, Pachkov M, Balwierz PJ, Jørgensen H, Stadler MB, van Nimwegen E, Schübeler D (2013) Modeling of epigenome dynamics identifies transcription factors that mediate Polycomb targeting. Genome Res 23:60-73. doi: CrossRef. [PMC] [10.1101/ gr.142661.112] [Medline]

Ballas N, Grunseich C, Lu DD, Speh J, Mandel G (2005) REST and its corepressors mediate plasticity of neuronal gene chromatin throughout neurogenesis. Cell 121:645-657. CrossRef Medline

Ballas N, Mandel G (2005) The many faces of REST oversee epigenetic programming of neuronal genes. Curr Opin Neurobiol 15: 500-506. CrossRef

Bersten DC, Wright JA, McCarthy PJ, Whitelaw ML (2014) Regulation of the neuronal transcription factor NPAS4 by REST and microRNAs. Biochim Biophys Acta 1839:13-24. CrossRef Medline

Bithell A, Johnson R, Buckley NJ (2009) Transcriptional dysregulation of coding and non-coding genes in cellular models of Huntington's disease. Biochem Soc Trans 37:1270-1275. CrossRef Medline

Bruce AW, Donaldson IJ, Wood IC, Yerbury SA, Sadowski MI, Chapman M, Göttgens B, Buckley NJ. (2004) Genome-wide analysis of repressor element 1 silencing transcription factor/neuronrestrictive silencing factor (REST/NRSF) target genes. Proc Natl Acad Sci U S A 101:10458-10463. CrossRef Medline

Buckley NJ, Johnson R, Zuccato C, Bithell A, Cattaneo E (2010) The role of REST in transcriptional and epigenetic dysregulation in Huntington's disease. Neurobiol Dis 39:28-39. CrossRef Medline

Cai L, Bian M, Liu M, Sheng Z, Suo H, Wang Z, Huang F, Fei J (2011) Ethanol-induced neurodegeneration in NRSF/REST neuronal conditional knockout mice. Neuroscience 181:196-205. CrossRef Medline

Calderone A, Jover T, Noh KM, Tanaka H, Yokota H, Lin Y, Grooms SY, Regis R, Bennett MV, Zukin RS (2003) Ischemic insults derepress the gene silencer REST in neurons destined to die. J Neurosci 23:2112-2121. Medline

Canzonetta C, Mulligan C, Deutsch S, Ruf S, O'Doherty A, Lyle R, Borel C, Lyn-Marq N, Delom F, Groet J, Schnappauf F, De Vita S, Averill S, Priest JV, Martin JE, Shipley J, Denyer G, Epstein CJ, Fillat C, Estivill X, Tybulewicz VL, Fisher EM, Antonarakis SE, Nizetic D (2008) DYRK1A-dosage imbalance perturbs NRSF/REST levels, deregulating pluripotency and embryonic stem cell fate in Down syndrome. Am J Hum Genet 83:388-400. CrossRef Medline

Charbord J, Poydenot P, Bonnefond C, Feyeux M, Casagrande F, Brinon B, Francelle L, Aurégan G, Guillermier $M$, Cailleret $M$, Viegas P, Nicoleau C, Martinat C, Brouillet E, Cattaneo E, Peschanski M, Lechuga M, Perrier AL. (2013) High throughput screening for inhibitors of REST in neural derivatives of neuronal genes. Stem Cells 31:1816-1828 CrossRef Medline

Chong JA, Tapia-Ramírez J, Kim S, Toledo-Aral JJ, Zheng Y, Boutros MC, Altshuller YM, Frohman MA, Kraner SD, Mandel G (1995) REST: a mammalian silencer protein that restricts sodium channel gene expression to neurons. Cell 80:949-957. Medline

Conaco C, Otto S, Han JJ, Mandel G (2006) Reciprocal actions of REST and microRNA promote neuronal identity. Proc Natl Acad Sci U S A 103:2422-2427. CrossRef Medline

Conforti P, Zuccato C, Gaudenzi G, leraci A, Camnasio S, Buckley NJ, Mutti C, Cotelli F, Contini, Cattaneo E (2013) Binding of the repressor complex REST-mSIN3b by small molecules restores neuronal gene transcription in Huntington's disease models. J Neurochem 127:22-35. CrossRef Medline

Crotti A, Benner C, Kerman BE, Gosselin D, Lagier-Tourenne C, Zuccato C, Cattaneo E, Gage FH, Cleveland DW, Glass CK (2014) Mutant huntingtin promotes autonomous microglia activation via myeloid lineage-determining factors. Nat Neurosci 17:513-521. CrossRef Medline

D'Alessandro R, Klajn A, Meldolesi J. (2009) Expression of densecore vesicles and of their exocytosis are governed by the repressive transcription factor NRSF/REST. Ann N Y Sci 1152:194-200.

Datta M, Bhattacharyya NP (2011) Regulation of RE-1 protein silencingtranscription factor (REST) expression by HIP1 protein interactor. J Biol Chem 286:33759-33769.

Didonna A, Opal P (2015) The promise and perils of HDAC inhibitors in neurodegeneration. Ann Clin Transl Neurol 2:79-101. CrossRef Medline

Dietrich N, Lerdrup M, Landt E, Agrawal-Singh S, Bak M, Tommerup N, Rappsilber J, Södersten E, Hansen K (2012) REST-mediated recruitment of polycomb repressor complexes in mammalian cells. PLoS Genet 8:e1002494. doi: CrossRef. [PMC] [10.1371/journal.pgen.1002494] [Medline]

Drews VL, Shi K, de Haan G, Meisler MH (2007) Identification of evolutionarily conserved, functional non-coding elements in the promoter region of the sodium channel gene SCN8A. Mamm Genome 18:723-731. CrossRef Medline

ENCODE Project Consortium (2012) An integrated encyclopedia of DNA elements in the human genome. Nature 489:57-74. CrossRef

Eom T, Zhang C, Wang H, Lay K, Fak J, Noebels JL, Darnell RB. (2013) NOVA-dependent regulation of cryptic NMD exons controls synaptic protein levels after seizure. Elife e00178. doi: CrossRef. [PMC] [10.7554/eLife.00178] [Medline]

Formisano L, Guida N, Laudati G, Boscia F, Esposito A, Secondo A, Di Renzo G, Canzoniero LM (2014) Extracellular signal-related 
kinase $2 /$ specificity protein 1 specificity protein $3 /$ repressor element-1 silencing transcription factor pathways involved in Arochlor 1254-induced toxicity in SH-SY5Y neuronal cells. J Neurosci Res 9:167-177.

Formisano L, Noh KM, Miyawaki T, Mashiko T, Bennett MV, Zukin RS (2007) Ischemia insults promote epigenetic reprogramming of $\mu$ opioid receptor expression in hippocampal neurons. Proc Natl Acad Sci U S A 104:4170-4175. CrossRef Medline

Gao Z, Ure K, Ding P, Nashaat M, Yuan L, Ma J, Hammer RE, Hsieh $J$ (2011) The master negative regulator REST/NRSF controls adult neurogenesis by restraining the neurogenic program in quiescent stem cells. J Neurosci 31:9772-9786. CrossRef Medline

Garriga-Canut M, Schoenike B, Qazi R, Bergendahl K, Daley TJ, Pfender RM, Morrison JF, Ockuly J, Stafstrom C, Sutula T, Roopra A (2006) 2-Deoxy-D-glucose reduces epilepsy progression by NRSF-CtBP-dependent metabolic regulation of chromatin structure. Nat Neurosci 9:1382-1387. CrossRef Medline

Goldberg EM, Coulter DA (2013) Mechanisms of epileptogenesis: a convergence on neural circuit dysfunction. Nat Rev Neurosci 14: 337-349. CrossRef Medline

González-Castañeda RE, Sánchez-González VJ, Flores-Soto M, Vázquez-Camacho G, Macías-Islas MA, Ortiz GG (2013) Neural restrictive silencer factor and choline acetyltransferase expression in cerebral tissue of Alzheimer's disease patients: a pilot study. Genet Mol Biol 36:28-36. CrossRef Medline

Gopalakrishnan V (2009) REST and the RESTless: in stem cells and beyond. Future Neurol 4:317-329. CrossRef Medline

Göttlicher M, Minucci S, Zhu P, Krämer OH, Schimpf A, Giavara S, Sleeman JP, Lo Coco F, Nervi C, Pelicci PG, Heinzel T (2001) Valproic acid defines a novel class of HDAC inhibitors inducing differentiation of transformed cells. EMBO J 20:6969-6978. CrossRef Medline

Gräff J, Tsai LH (2013) The potential of HDAC inhibitors as cognitive enhancers. Annu Rev Pharmacol Toxicol 53:311-330. CrossRef Medline

Greenway DJ, Street M, Jeffries A, Buckley NJ (2007) Distinct profiles of REST interactions with its target genes at different stages of neuronal development. Stem Cells 25:354-363.

Hara D, Fukuchi M, Miyashita T, Tabuchi A, Takasaki I, Naruse Y, Mori N, Kondo T, Tsuda M (2009) Remote control of activitydependent BDNF gene promoter-I transcription mediated by REST/NRSF. Biochem Biophys Res Commun 384:506-511. CrossRef Medline

Henriksson R, Bäckman CM, Harvey BK, Kadyrova H, Bazov I, Shippenberg TS, Bakalkin G (2014) PDYN, a gene implicated in brain/mental disorders, is targeted by REST in the adult human brain. Biochim Biophys Acta 1839:1226-1232. CrossRef Medline

Hu XL, Cheng X, Cai L, Tan GH, Xu L, Feng XY, Lu TJ, Xiong H, Fei $\mathrm{J}$, Xiong ZQ (2011a) Conditional deletion of NRSF in forebrain neurons accelerates epileptogenesis in the kindling model. Cereb Cortex 21:2158-2165. CrossRef Medline

Hu XL, Cheng X, Fei J, Xiong ZQ (2011b) Neuron-restrictive silencer factor is not required for the antiepileptic effect of the ketogenic diet. Epilepsia 52:1609-1618. CrossRef Medline

Huang Y, Myers SJ, Dingledine R (1999) Transcriptional repression by REST: recruitment of Sin3A and histone deacetylase to neuronal genes. Nat Neurosci 2:867-872. CrossRef Medline

Huang Z, Bao S (2012) Ubiquitination and deubiquitination of REST and its roles in cancers. FEBS Lett 586:1602-1605. CrossRef Medline

Huang Z, Wu Q, Guryanova OA, Cheng L, Shou W, Rich JN, Bao S (2011) Deubiquitilase HAUSP stabilizes REST and promotes maintenance of neural progenitor cells. Nat Cell Biol 13:142-152. CrossRef Medline

Hwang JY, Kaneko N, Noh KM, Pontarelli F, Zukin RS (2014) The gene silencing transcription factor REST represses miR-132 expression in hippocampal neurons destined to die. J Mol Biol 426:3454-3466. CrossRef Medline

Jessberger S, Nakashima K, Clemenson GD Jr, Mejia E, Mathews E, Ure K, Ogawa S, Sinton CM, Gage FH, Hsieh J (2007) Epigenetic modulation of seizure-induced neurogenesis and cognitive decline. J Neurosci 27:5967-5975. CrossRef Medline

Jia YH, Zhu X, Li SY, Ni JH, Jia HT (2006) Kainate exposure suppresses activation of GluR2 subunit promoter in primary cultured cerebral cortical neurons through induction of RE-1-silencing transcription factor. Neurosci Lett 403:103-108. CrossRef

Jobe EM, McQuate AL, Zhao X (2012) Crosstalk among epigenetic pathways regulates neurogenesis. Front Neurosci 6:59 CrossRef Medline

Johnson DS, Mortazavi A, Myers RM, Wold B (2007) Genome-wide mapping of in vivo protein-DNA interactions. Science 316:14971502. CrossRef Medline

Johnson P, Lipovich L, Grandér D, Morris KV (2014) Evolutionary conservation of long non-coding RNAs; sequence, structure, function. Biochim Biophys Acta 1840:1063-1071. CrossRef Medline

Johnson R, Teh CH, Kunarso G, Wong KY, Srinivasan G, Cooper ML, Volta M, Chan SS, Lipovich L, Pollard SM, Karuturi RK, Wei CL, Buckley NJ, Stanton LW (2008) REST regulates distinct transcriptional networks in embryonic and neural stem cells. PLoS Biol 6:e256. CrossRef Medline

Johnson R, Teh CH, Jia H, Vanisri RR, Pandey T, Lu ZH, Buckley NJ, Stanton LW, Lipovich L (2009) Regulation of neural macroRNAs by the transcriptional repressor REST. RNA 5:85-96.

Johnson R, Richter N, Bogu GK, Bhinge A, Teng SW, Choo SH, Andrieux LO, de Benedictis C, Jauch R, Stanton LW (2012) A genome-wide screen for genetic variants that modify the recruitment of REST to its target genes. PLoS Genet 8:e1002624. CrossRef Medline

Jørgensen HF, Terry A, Beretta C, Pereira CF, Leleu M, Chen ZF, Kelly C, Merkenschlager M, Fisher AG (2009) REST selectively represses a subset of $\mathrm{RE}-1$ containing neuronal genes in mouse embryonic stem cells. Development 136:715-721. CrossRef Medline

Juliandi B, Abematsu M, Nakashima K (2010) Chromatin remodeling in neural stem differentiation. Curr Opin Neurobiol 20:408-415. CrossRef Medline

Kaneko N, Hwang JY, Gertner M, Pontarelli F, Zukin RS (2014) Casein kinase 1 suppresses activation of REST in insulted hippocampal neurons and halts ischemia-induced neuronal death. $J$ Neurosci 34:6030-6039. CrossRef Medline

Kim CS, Hwang CK, Choi HS, Song KY, Law PY, Wei LN, Loh HH (2004) Neuron-restrictive silencer factor (NRSF) functions as a repressor in neuronal cells to regulate the mu opioid receptor gene. J Biol Chem 279:46464-46473. CrossRef

Kuwabara T, Hsieh J, Nakashima K, Warashina M, Taira K, Gage FH (2005) The NRSE smRNA specifies the fate of the adult hippocampal neural stem cells. Nucleic Acids Symp Ser (Oxf) 49:87-88. CrossRef

Lau A, Tymianski M (2010) Glutamate receptors, neurotoxicity and neuro-degeneration. Pflugers Arch 460:525-542. CrossRef Medline

Lau P, Bossers K, Janky R, Salta E, Frigerio CS, Barbash S, Rothman R, Sierksma AS, Thathiah A, Greenberg D, Papadopoulou AS, Achsel T, Ayoubi T, Soreq H, Verhaagen J, Swaab DF, Aerts S, De Strooper B (2013) Alteration of the microRNA network during the progression of Alzheimer's disease. EMBO Mol Med 5:1613-1634. CrossRef Medline

Lawn S, Krishna N, Pisklakova A, Qu X, Fenstermacher DA, Fournier M, Vrionis FD, Tran N, Chan JA, Kenchappa RS, Forsyth PA (2015) Neurotrophin signaling via TrkB and TrkC receptors promotes the growth of brain tumor-initiating cells. J Biol Chem 290:3814-3824. CrossRef Medline

Lee JH, Tecedor L, Chen YH, Monteys AM, Sowada MJ, Thompson LM, Davidson BL (2015) Reinstating aberrant mTORC1 activity in Huntington's disease mice improves disease phenotypes. Neuron 85:303-315. CrossRef Medline

Lepagnol-Bestel AM, Zvara A, Maussion G, Ngimbous B, Ramoz N, Imbeaud, Loe-Mie Y, Benihoud K, Agier N, Salin PA, Cardona A, Khung-Savatovsky S. Kallunki P, Delabar JM, Puskas LG, Delacroix H, Aggerbeck L, Delezoide A, Delattre O, Gorwood P, Moalic 
JM, Simonneau M (2009) Dyrk1A interacts with the REST/NRSFSWI/SNF chromatin remodelling complex to deregulate gene clusters involved in neuronal phenotypic traits of Down syndrome. Hum Mol Genet 18:1405-1414. CrossRef Medline

Liu M, Sheng Z, Cai L, Zhao K, Tian Y, Fei J. (2012) Neuronal conditional knockout of NRSF decreases vulnerability to seizures induced by pentylenetetrazol in mice. Acta Biochim Biophys Sin (Shanghai) 44:476-482. CrossRef Medline

Loe-Mie Y, Lepagnol-Bestel AM, Maussion G, Doron-Faigenboim A, Imbeaud S, Delacroix H, Aggerbeck L, Pupko T, Gorwood P, Simonneau M, Moalic JM (2010) SMARCA2 and other genomewide supported schizophrenia-associated genes: regulation by REST/NRSF, network organization and primate-specific evolution. Hum Mol Genet 19:2841-2857. CrossRef

Lu T, Aron L, Zullo J, Pan Y, Kim H, Chen Y, Yang TH, Kim HM, Drake D, Liu XS, Bennett DA, Colaiácovo MP, Yankner BA (2014) REST and stress resistance in ageing and Alzheimer's disease. Nature 507:448-454. CrossRef Medline

Lungu G, Stoica G, Ambrus A (2013) MicroRNA profiling and the role of microRNA-132 in neurodegeneration using a rat model. Neurosci Lett 553:153-158. CrossRef Medline

Martin DD, Ladha S, Ehrnhoefer DE, Hayden MR (2015) Autophagy in Huntington disease and huntingtin in autophagy. Trends Neurosci 38:26-35. CrossRef Medline

McClelland S, Brennan GP, Dubé C, Rajpara S, lyer S, Richichi C, Bernard C, Baram TZ (2014) The transcription factor NRSF contributes to epileptogenesis by selective repression of a subset of target genes. eLife 3:e01267. doi: 10.7554/eLife.01267. Medline

McClelland S, Flynn C, Dubé C, Richichi C, Zha Q, Ghestem A, Esclapez M, Bernard C, Baram TZ (2011a) Neuron-restrictive silencer factor-mediated hyperpolarization-activated cyclic nucleotide gated channelopathy in experimental temporal lobe epilepsy. Ann Neurol 70:454-464.

McClelland S, Korosi A, Cope J, Ivy A, Baram TZ (2011b) Emerging roles of epigenetic mechanisms in the enduring effects of early-life stress and experience on learning and memory. Neurobiol Learn Mem 96:79-88. CrossRef Medline

Mikulak J, Negrini S, Klajn A, D'Alessandro R, Mavilio D, Meldolesi J (2012) Dual REST-dependence of L1CAM: from gene expression to alternative splicing governed by Nova2 in neural cells. J Neurochem 120:699-709. CrossRef Medline

Moreno-González G, López-Colomé AM, Rodríguez G, ZarainHerzberg A (2008) Transcription of the chicken Grin1 gene is regulated by the activity of SP3 and NRSF in undifferentiated cells and neurons. Biosci Rep 28:177-188. CrossRef Medline

Mortazavi A, Leeper Thompson EC, Garcia ST, Myers RM, Wold B (2006) Comparative genomics modeling of the NRSF/REST repressor network: from single conserved sites to genome-wide repertoire. Genome Res 16:1208-1221. CrossRef Medline

Mulligan P, Westbrook TF, Ottinger M, Pavlova N, Chang B, Macia E, Shi YJ, Barretina J, Liu J, Howley PM, Elledge SJ, Shi Y (2008) CDYL bridges REST and histone methyltransferases for gene repression and suppression of cellular transformation. Mol Cell 32:718-726. CrossRef Medline

Murai K, Naruse Y, Shaul Y, Agata Y, Mori N.T (2005) Direct interaction of NRSF with TBP: chromatin reorganization and core promoter repression for neuron-specific gene transcription. J Mol Biol 354:903-915.

Nadeau H, Lester HA (2002) NRSF causes cAMP-sensitive suppression of sodium current in cultured hippocampal neurons. J Neurophysiol 88:409-421. Medline

Nakatani T, Ueno S, Mori N, Matsuoka I (2005) Role of NRSF/REST in the molecular mechanisms regulating neural-specific expression of trkC/neurotrophin-3 receptor gene. Brain Res Mol Brain Res 135:249-259. CrossRef Medline

Negrini S, D'Alessandro R, Meldolesi J (2013b) NGF signaling in PC12 cells: the cooperation of p75(NTR) with TrkA is needed for the activation of both mTORC2 and the PI3K signaling cascade. Biol Open 2:855-866. CrossRef Medline
Negrini S, Prada I, D’Alessandro R, Meldolesi J (2013a) REST: an oncogene or a tumor suppressor? Trends Cell Biol 23:289-295. CrossRef Medline

Nishihara S, Tsuda L, Ogura T (2003) The canonical WNT pathway directly regulates NRSF/REST expression in chick spinal cord. Biochem Biophys Res Comm 311:55-63. CrossRef

Noh FM, Hwang JY, Follenzi A, Athanasiadou R, Miyawaki T, Greally JM, Bennett ML, Zukin RS (2012) Repressor element-1 silencing transcription factor (REST)-dependent epigenetic remodeling is critical to ischemia-induced neuronal death. Proc Natl Acad Sci U S A E962-E971. CrossRef

Ono K, lijima T (2010) Cardiac T-type $\mathrm{Ca}(2+)$ channels in the heart. $\mathrm{J}$ Mol Cell Cardiol 48:65-70. CrossRef Medline

Ooi L, Wood IC (2007) Chromatin crosstalk in development and disease: lessons from REST. Nat Rev Genet 8:544-554. CrossRef Medline

Orta-Salazar E, Aguilar-Vázquez A., Martínez-Coria H, Luquín-De Anda S, Rivera-Cervantes M, Beas-Zarate C, Feria-Velasco A, Díaz-Cintra S (2014) REST/NRSF-induced changes of ChAT protein expression in the neocortex and hippocampus of the 3xTg-AD mouse model for Alzheimer disease. Life Sci 116:83-89. CrossRef Medline

Ortuño-Sahagún D, González RM, Verdaguer E, Huerta VC, TorresMendoza BM, Lemus L, Rivera-Cervantes MC, Camins A, Zárate CB (2014) Glutamate excitotoxicity activates the MAPK/ERK signaling pathway and induces the survival of rat hippocampal neurons in vivo. J Mol Neurosci 52:366-377. CrossRef Medline

Otto SJ, McCorkle SR, Hover J, Conaco C, Han JJ, Impey S, Yochum GS, Dunn JJ, Goodman RH, Mandel G (2007) A new binding motif for the transcriptional repressor REST uncovers large gene networks devoted to neuronal functions. J Neurosci 27:67296739. CrossRef Medline

Palm K, Belluardo M, Metsis M, Timmusk T (1998) Neuronal expression of zinc finger transcription factor REST/NRSF/XBR gene. $J$ Neurosci 18:1280-1296. Medline

Paonessa F, Latifi S, Scarongella H, Cesca F, Benfenati F. (2013) Specificity protein 1 (Sp1)-dependent activation of the synapsin I gene (SYN1) is modulated by RE1-silencing transcription factor (REST) and 5'-cytosine-phosphoguanine (CpG) methylation. J Biol Chem 2013 288:3227-3239. CrossRef Medline

Paquette AJ, Perez SE, Anderson DJ. (2000) Constitutive expression of the neuron-restrictive silencer factor (NRSF)/REST in differentiating neurons disrupts neuronal gene expression and causes axon pathfinding errors in vivo. Proc Natl Acad Sci U S A 97:1231812323. CrossRef Medline

Penney J, Tsai LH (2014) Histone deacetylases in memory and cognition. Sci Signal 7:re12. doi: CrossRef. [PMC] [10.1126/scisignal.aaa0069] [Medline]

Pozzi D, Lignani G, Ferrea E, Contestabile A, Paonessa F, D'Alessandro R, Lippiello $P$, Boido D, Fassio A, Meldolesi J, Valtorta F, Benfenati F, Baldelli P (2013) REST/NRSF-mediated intrinsic homeostasis protects neuronal networks from hyperexcitability. EMBO J 32:2994-3007. CrossRef Medline

Prada I, Marchaland J, Podini P, Magrassi L, D'Alessandro R, Bezzi P, Meldolesi J. (2011) REST/NRSF governs the expression of dense-core vesicle gliosecretion in astrocytes. J Cell Biol 193:537549. CrossRef Medline

Qiang M, Rani CS, Ticku MK (2005) Neuron-restrictive silencer factor regulates the $\mathrm{N}$-methyl-D-aspartate receptor $2 \mathrm{~B}$ subunit gene in basal and ethanol-induced gene expression in fetal cortical neurons. Mol Pharmacol 67:2115-2125. CrossRef

Raj B, O'Hanlon D, Vessey JP, Pan Q, Ray D, Buckley NJ, Miller DF, Blencowe BJ (2011) Cross-regulation between an alternative splicing activator and a transcription repressor controls neurogenesis. Mol Cell 43:843-850. CrossRef Medline

Ravache M, Weber C, Mérienne K, Trottier Y (2010) Transcriptional activation of REST by Sp1 in Huntington's disease models. PLoS One. 5:e14311. doi: CrossRef. [PMC] [10.1371/journal.pone.0014311] [Medline] 
Rivera-Cervantes $M C$, Castañeda-Arellano R, Castro-Torres RD, Gudiño-Cabrera G, Feria y Velasco Al, Camins A, Beas-Zárate C (2015) P38 MAPK inhibition protects against glutamate neurotoxicity and modifies NMDA and AMPA receptor subunit expression. $\mathrm{J}$ Mol Neurosci 55:596-608. CrossRef Medline

Rodenas-Ruano A, Chávez AE, Cossio MJ, Castillo PE, Zukin S (2012) Rest-dependent epigenetic remodeling promotes the developmental switch in synaptic NMDA receptors. Nat Neurosci 15:1382-1389. CrossRef Medline

Roopra A., Dingledine R, Hsieh J (2012) Epigenetics and epilepsy. Epilepsia 53 [Suppl 9]:2-10. CrossRef Medline

Rossbach M (2011) Non-coding RNAs in neural networks, RESTassured. Front Genet 2:8. doi.103389/fgene2011.00008.

Rusconi F, Paganini L, Braida D, Ponzoni L, Toffolo E, Maroli A, Landsberger N, Bedogni F, Turco E, Pattini L, Altruda F, De Biasi S, Sala M, Battaglioli E (2014) LSD1 neurospecific alternative splicing controls neuronal excitability in mouse models of epilepsy. Cereb Cortex. Advance online publication. Retrieved 2 July 2015. doi:10.1093/cercor/bhu070.

Sanuki R, Onishi A, Koike C, Muramatsu R, Watanabe S, Muranishi $\mathrm{Y}$, Ine S, Uneo S, Koyasu T, Matsui R, Chérasse $\mathrm{Y}$, Urade $\mathrm{Y}$, Watanabe D, Kondo M, Yamashita T, Furukawa T. (2011) miR$124 a$ is required for hippocampal axogenesis and retinal cone survival through Lhx2 suppression. Nat Neurosci 14:1125-1134. CrossRef Medline

Schoch S, Cibelli G, Thiel G. (1996) Neuron-specific gene expression of synapsin I. Major role of a negative regulatory mechanism. J Biol Chem 271:3317-3323. Medline

Schoenherr CJ, Anderson DJ (1995) The neuron-restrictive silencer factor (NRSF): a coordinate repressor of multiple neuron-specific genes. Science 267:1360-1363. Medline

Schonrock N, Humphreys DT, Preiss T, Götz J (2012) Target gene repression mediated by miRNAs miR-181c and miR-9 both of which are down-regulated by amyloid- $\beta$. J Mol Neurosci 46:324335. CrossRef Medline

Shimojo M (2006) Characterization of the nuclear targeting signal of REST/NRSF. Neurosci Lett 398:161-166. CrossRef Medline

Siegel G, Saba R, Schratt G (2011) microRNAs in neurons: manifold regulatory roles at the synapse. Curr Opin Genet Dev 21:491-497. CrossRef Medline

Singh A, Rokes C, Gireud M, Fletcher S, Baumgartner J, Fuller G, Stewart J, Zage P, Gopalakrishnan V (2011) Retinoic acid induces REST degradation and neuronal differentiation by modulating the expression of $\operatorname{SCF}(\beta$-TRCP) in neuroblastoma cells. Cancer 117: 5189-51202. CrossRef Medline

Soldati C, Bithell A, Conforti P, Cattaneo E, Buckley NJ. (2011) Rescue of gene expression by modified REST decoy oligonucleotides in a cellular model of Huntington's disease. J Neurochem 116:415-425. CrossRef Medline

Spencer EM, Chandler KE, Haddley K, Howard MR, Belyaev ND, Coulson JM, Stewart JP, Buckley NJ, Kipar A, Walker MG, Quinn JP (2006) Regulation and role of REST and REST4 variants in modulation of gene expression in vivo and in vitro in epilepsy models. Neurobiol Dis 24:41-52. CrossRef Medline

Sun AX, Crabtree GR, Yoo AS (2013) MicroRNAs: regulators of neuronal fate. Curr Opin Cell Biol 25:215-221. CrossRef Medline

Sun YM, Greenway DJ, Johnson R, Street M, Belyaev ND, Deuchars J, Bee T, Wilde S, Buckley NJ (2005) Distinct profiles of REST interactions with its target genes at different stages of neuronal development. Mol Biol Cell 16:5630-5638. CrossRef Medline

Tahiliani M, Mei P, Fang R, Leonor T, Rutenberg M, Shimizu F, Li J, Rao A, Shi $\mathrm{Y}$ (2007) The histone $\mathrm{H}_{3} \mathrm{~K}_{4}$ demethylase SMCX links REST target genes to X-linked mental retardation. Nature 447:601605. CrossRef

Tejeda HA, Shippenberg TS, Henriksson R (2012) The dynorphin/ $\kappa^{-}$ opioid receptor system and its role in psychiatric disorders. Cell Mol Life Sci 69:857-896. CrossRef Medline

Tunnicliff G (1999) Actions of sodium valproate on the central nervous system. J Physiol Pharmacol 50:347-365. Medline
Uchida H, Sasaki K, Ma L, Ueda H (2010) Neuron-restrictive silencer factor causes epigenetic silencing of $\mathrm{K}_{\mathrm{v}} 4.3$ gene after peripheral nerve injury. Neurosci 166:1-4. CrossRef Medline

Ule J, Ule A, Spencer J, Williams J, Williams A, Hu JS, Cline M, Wang $H$, Clark T, Fraser C, Ruggiu M, Zeeberg BR, Kane D, Weinstein JN, Blume J, Darnell RB. (2005) Nova regulates brain-specific splicing to shape the synapse. Nat Genet 37:844-852. CrossRef

Uvarov P, Pruunsild P, Timmusk T, Airaksinen MS (2005) Neuronal $\mathrm{K}+/ \mathrm{Cl}$ - co-transporter ( $\mathrm{KCC} 2$ ) transgenes lacking neurone restrictive silencer element recapitulate CNS neurone-specific expression and developmental up-regulation of endogenous KCC2 gene. J Neurochem 95:1144-1155. CrossRef

Van Loo K, Schaub C, Pernhorst K, Yaari Y, Beck H, Schoch S, Becker AJ (2012) Transcriptional regulation of the T-type calcium channel Cav3.2 bidirectionality by early growth response (Egr1) and Re-1 silencing transcription factor (REST). J Biol Chem 287: 15489-15501.

Vogel-Ciernia A, Matheos DP, Barrett RM, Kramár EA, Azzawi S, Chen Y, Magnan CN, Zeller M, Sylvain A, Haettig J, Jia Y, Tran A, Dang R, Post RJ, Chabrier M, Babayan AH, Wu JI, Crabtree GR, Baldi P, Baram TZ, Lynch G, Wood MA (2013) The neuron-specific chromatin regulatory subunit BAF53b is necessary for synaptic plasticity and memory. Nat Neurosci 16:552-561. CrossRef Medline

Volvert ML, Prévot PP, Close P, Laguesse S, Pirotte S, Hemphill J, Rogister F, Kruzy N, Sacheli R, Moonen G, Deiters A, Merkenschlager M, Chariot A, Malgrange B, Godin JD, Nguyen L (2014) MicroRNA targeting of CoREST controls polarization of migrating cortical neurons. Cell Rep 7:1168-1183. CrossRef Medline

Wagoner MP, Gunsalus KT, Schoenike B, Richardson AL, Friedl A, Roopra A (2010) The transcription factor REST is lost in aggressive breast cancer. PLoS Genet 6:e1000979. CrossRef Medline

Westbrook TF, Hu G, Ang XL, Mulligan P, Pavlova NN, Liang A, Leng Y, Maehr R, Shi Y, Harper JW, Elledge SJ. (2008) SCFbeta-TRCP controls oncogenic transformation and neural differentiation through REST degradation. Nature 452:370-374. CrossRef Medline

Westbrook TF, Martin ES, Schlabach MR, Leng Y, Liang AC, Feng B, Zhao JJ, Roberts TM, Mandel G, Hannon GJ, Depinho RA, Chin L, Elledge SJ. (2005) A genetic screen for candidate tumor suppressors identifies REST. Cell 121:837-848. CrossRef Medline

Willert J, Epping M, Pollack JR, Brown PO, Nusse R. (2002) A transcriptional response to Wnt protein in human embryonic carcinoma cells. BMC Dev Biol 2:8. Medline

Wu J, Xie X (2006) Comparative sequence analysis reveals an intricate network among REST, CREB and miRNA in mediating neuronal gene expression. Genome Biol 7:R85. CrossRef Medline

Wu P, Zuo X, Deng H, Liu X, Liu L, Ji A (2013) Roles of long noncoding RNAs in brain development, functional diversification and neurodegenerative diseases. Brain Res Bull. 97:69-80. CrossRef Medline

Yeo M, Berglund K, Augustine G, Liedtke W (2009) Novel repression of KCC2 transcription by REST-RE-1 controls developmental switch in neuronal chloride. J Neurosci 29:14652-14662. CrossRef Medline

Yoo AS, Staahl BT, Chen L, Crabtree GR (2009) MicroRNA-mediated switching of chromatin-remodelling complexes in neural development. Nature 460:642-646. CrossRef Medline

Yu M, Cai L, Liang M, Huang Y, Gao H, Lu S, Fei J, Huang F (2009) Alteration of NRSF expression exacerbating 1-methyl-4-phenylpyridinium ion-induced cell death of SH-SY5Y cells. Neurosci Res 65:236-244. CrossRef Medline

Yu M, Suo H, Liu M, Cai L, Huang Y, Xu J, Wang Y, Zhu C, Fei J, Huang $F(2013)$ NRSF/REST neuronal deficient mice are more vulnerable to the neurotoxin MPTP. Neurobiol Aging 34:916-927. CrossRef Medline

Yuan Y, Chow BK, Lee VH, Lee LT (2013) Neuron-restrictive silencer factor functions to suppress SP1-mediated transactivation of human secretin receptor gene. Biochim Biophys Acta 1829:231-238. CrossRef 
Zhang J, Wang S, Yuan L, Yang Y, Zhang B, Liu Q, Chen L, Yue W, Li Y, Pei X (2012) Neuron-restrictive silencer factor (NRSF) represses cocaine and amphetamine-regulated transcript (CART) transcription and antagonizes cAMP-response element binding protein signaling through a dual NRSE mechanism. J Biol Chem 287:42574-42587. CrossRef Medline

Zuccato C, Belyaev N, Conforti P, Ooi L, Tartari M, Papadimou E, MacDonald M, Fossale E, Zeitlin S, Buckley N, Cattaneo E. (2007) Wide- spread disruption of repressor element-1 silencing transcription factor/ neuron-restrictive silencer factor occupancy at its target genes in Huntington's disease. J Neurosci 27:6972-6983. CrossRef Medline Zuccato C, Tartari M, Crotti A, Goffredo D, Valenza M, Conti L, Cataudella T, Leavitt BR, Hayden MR, Timmusk T, Rigamonti D, Cattaneo E (2003) Huntingtin interacts with REST/NRSF to modulate the transcription of NRSE-controlled neuronal genes. Nat Genet 35:76-83. CrossRef Medline 